American Journal of Applied Sciences 6 (3): 439-444, 2009

ISSN 1546-9239

(C) 2009 Science Publications

\title{
Survival of Vibrio cholerae 0139 in Association with Anabaena variabilis in Four Different Microcosoms
}

\author{
Zannatul Ferdous \\ Department of Zoology, University of Dhaka, Dhaka-1000, Bangladesh
}

\begin{abstract}
Investigation was carried out to see the association of Vibrio cholerae O139 with Anabaena variabilis, in four different types of water. Conventional media were used to count culturable bacteria while epi fluorescence microscopy to count the viable but non culturable (VBNC) V. cholerae O139. It was found that the culturable form of $V$. cholerae $\mathrm{O} 139$ found 9 days in the control artificial sea water and 4 days in river water and BOD dilution water. However, in association with A. variabilis, culturable form was found for 6 days in artificial sea water, 4 days in distilled water, 1 day in BOD dilution water, 4 days in river water. The bacterial count of surrounding water decreased inversely with the bacterial count in association with algae. Among these four microcosm water, associations of $V$. cholerae $\mathrm{O} 139$ with algae was higher in artificial sea water. In control water of four microcosms, direct viable count (DVC) gradually decreased with time. In association with algae the DVC increased after some time then reached a peak in 4-8 days depending on the types of water. The epi fluorescence microscopy indicated that $V$. cholerae 0139 survived for more than one month in association with algae. Present study demonstrated that survival of $V$. cholerae 0139 appears to get advantages in association with $A$. variabilis in different types of water.
\end{abstract}

Key words: Water type, Vibrio cholerae, microcosm

\section{INTRODUCTION}

Cholera which is a major public-health problem in developing countries, caused by infection of the intestine with toxigenic Vibrio cholera $e^{[1]}$. Inhealth children, HIV patients are at vulnerable risk of death if infected by this disease. Even this disease can kill a healthy adult within hours. A global cholera update by World Health Organization (WHO) indicates a grand total of about 236-896 cases of cholera from 52 countries with about 6311 deaths which is overall $79 \%$ higher than the number of cases notified in $2005^{[2]}$. Bangladesh and other South Asian countries is endemic zone for cholera. Cholera is endemic in Bangladesh and maintains a regular seasonal pattern ${ }^{[3]}$. In this country, cholera epidemics occur twice every year, the highest peak during post monsoon (September-January) and second smaller peak during pre monsoon (March-May). During interepedemic period $V$. cholerae cannot be cultured from the surface water whereas in epidemic season it can be isolated from the patient body as well as from surface water ${ }^{[4]}$.

$V$. cholerae $\mathrm{O} 139$ have been identified as an etiological agent of cholera since $1993^{[5]}$. Out of 150 sero groups, only $V$. cholerae $\mathrm{O} 1$ and $\mathrm{O} 139$ are related to the epidemics of cholera ${ }^{[5,6,7]}$. The rest of the non $\mathrm{O} 1$ and non $\mathrm{O} 139$ serogroups of $V$. cholerae do not have epidemic and pandemic potential ${ }^{[8]}$. They are known to cause sporadic or small outbreaks of diarrhoea and extra intestinal infections ${ }^{[9]}$. When $V$. cholerae is not wreaking havoc in the human intestine, it may be found in diverse aquatic environments such as estuaries, rivers, ponds etc. ${ }^{[7,10]}$. In the aquatic environment $V$. cholerae can survive either as free living planktonic organisms in the water column or associated with phytoplankton and zooplankton ${ }^{[11,12] .}$ In natural habitat $V$. cholerae remains attached to Anabaena sp and $V$. cholerae $\mathrm{O} 1$ was found to be persistent in the mucilaginous sheath of a blue green alga A. variabilis in the artificial aquatic environment ${ }^{[13]}$.

Some investigators studied viability of $V$. cholerae O1 in different aquatic environment. Pruzzo et al., ${ }^{[14]}$ found that in artificial sea water $V$. cholerae $\mathrm{O} 1$ remain viable for 40 days without loosing their adhesive properties in presence of copepods and chitin. Feachem $^{[15]}$ demonstrated that $V$. cholerae survived upto one month at $4^{\circ} \mathrm{C}$ and $2-14$ days at $20-30^{\circ} \mathrm{C}$ in clean water.

The occurrence of culturable V. cholerae $\mathrm{O} 139$ in various components of the aquatic environment in Bangladesh has been published in $1996^{[16]}$. However, a few studies have been done in regard to the association of $V$. cholerae $\mathrm{O} 139$ with blue green algae with respect to changes in physicochemical features of water. 
During the present study, attempts were made to compare the growth pattern (both in culturable and nonculturable state) of $V$. cholerae $\mathrm{O} 139$ in association with $A$. variabilis in four different types of water VIZ. artificial sea water, distilled water, river water and BOD dilution water. If this virulent agent of cholera has got broad spectrum survival, it would have a greater potency of availability in nature; this would help in public health safety.

\section{MATERIALS AND METHODS}

Bacteria and algae strains and Preparation of inoculum: A strain of $V$. cholerae O139 (1852), an environmental strain was collected from the Environmental Microbiology Lab of ICDDR, B. This strain was reconfirmed by culture, biochemical and serological, physiological and molecular technique ${ }^{[17]}$. The A. variabilis belonging to the phylum Cyanophyta, used in this study was initially collected from the department of Botany, Bangladesh, DU, Bangladesh and maintained as pure culture for long time at Enviromental Microbiology Lab of ICDDR,B, Dhaka.For the current study algae was used from this stock culture and all experiments were conducted at International Centre for Diarrhoeal Disease Research, Bangladesh ( ICDDR,B).

$V$. cholerae $\mathrm{O} 139$ strains were cultured on taurocholate tellurite gelatine agar (TTGA ) plates at $37^{\circ} \mathrm{C}$ for $18-24 \mathrm{hrs}$ by following small modification of previously published method ${ }^{[1]}$. In previous method, inoculum was prepared in $7 \mathrm{~mL} 0.1 \% \mathrm{NaCl}$ solution (pH 7.0) but in this experiment prepared by mixing properly a loopful of culture in $5 \mathrm{~mL} 0.1 \% \mathrm{NaCl}(\mathrm{pH}$ 7.0) saline water. To make sure concentration of the prepared inoculum was $\log _{10} 7$ cells $\mathrm{mL}^{-1}$, was compared with 0.5 standard MacFarland solution. A cell count per millilitre was determined by using drop plate method $^{[18]}$.

Preparation of microcosm water: Four types of water VIZ. artificial sea water, distilled water, river water and BOD dilution water were used in four different microcosms in this study. Artificial sea water and BOD dilution water were prepared in the laboratory using method which was devised by Kester, Duedal, Cannors and Pytokowicz (1967) ${ }^{[19]}$ and standard method ${ }^{[20]}$ respectively. Artificial sea water was prepared by adding $\mathrm{NaCl}$ ( $23.926 \mathrm{G} \mathrm{kg}^{-1}$ of solution), $\mathrm{Na}_{2} \mathrm{SO}_{4}$

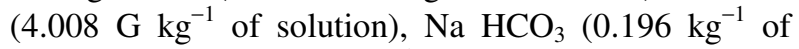
solution), $\mathrm{KCl}\left(0.677 \mathrm{G} \mathrm{kg}^{-1}\right.$ of solution), $\mathrm{KBr}(0.098 \mathrm{G}$ $\mathrm{kg}^{-1}$ of solution), $\mathrm{MgCl}_{2}\left(1.071 \mathrm{~g} \mathrm{~mL}^{-1}\right), \mathrm{CaCl}_{2}(1.085 \mathrm{~g}$
$\mathrm{mL}^{-1}$ ) in $1000 \mathrm{~mL}$ distilled water. BOD dilution water was prepared by adding Phosphate buffer solution $(8.5 \mathrm{~g}$ $\mathrm{KH}_{2} \mathrm{PO}_{4}+21.75 \mathrm{~g} \quad \mathrm{~K}_{2} \mathrm{HPO}_{4}+33.4 \mathrm{~g} \quad \mathrm{Na}_{2} \mathrm{HPO}_{4} .7 \mathrm{H}_{2} \mathrm{O}+1.7 \mathrm{~g}$ $\left.\mathrm{NH}_{4} \mathrm{Cl}\right)$, Magnesium sulphate solution (22.5g $\mathrm{MgSO}_{4} .7 \mathrm{H}_{2} \mathrm{O}$ ), Calcium choloride (27.5g), Feric choloride $(0.25 \mathrm{~g})$, in $1000 \mathrm{~mL}$ distilled water. River water was collected from Dhonagoda river of Matlab, Bangladesh.

Survival experiment for culturable growth: Hundred milliliter of artificial sea water, distilled water, river water, BOD dilution water respectively was inoculated with defined number of $V$. cholerae and $1 \mathrm{gm}$ wet Anabaena sp. was added from pure culture in $250 \mathrm{~mL}$ experimental flasks. One control flask (with defined number of $V$. cholerae but without algae) was used for every experimental flask. Sampling was performed from each experimental and control flask after 30 minutes was considered as $0 \mathrm{~h}$ reading. The samples were cultured in two TTGA media ${ }^{[21]}$ seperately. The steps of this experiment were followed by the procedures described by Islam et al. ${ }^{[1]}$ with few changes in amount In brief, $0.05 \mathrm{gm}$ wet weight of algae were collected with the help of a sterile spatula and then gently squeezed on the glass walls of the flasks to remove the excess water. This algae was homogenized manually in the glass made homogenizer with $1 \mathrm{~mL}$ $0.1 \%$ saline water. Then tenfold serial dilution was prepared and $25 \mu \mathrm{L}$ proportions from each dilution were inoculated and spread on to the duplicated TTGA plates. The plates were incubated at $37^{\circ} \mathrm{C}$ for $24 \mathrm{~h}$ and the bacterial counts were derived from counts of individual colonies and expressed as $\mathrm{CFU} \mathrm{mL} \mathrm{m}^{-1}$ or gm (colony forming unit). Duplicated plates were used to average the bacterial count for each dilution.

Flurescent microscopy for viable but nonculturable growth: When the cells of V.choleraeO139 were failed to grow on TTGA media, they were thought to be enter the non-culturable state and samples were subjected to fluorescent antibody test according to the procedure described by Islam et $a l .{ }^{[22]}$ to detect the non- culturable state and to detect direct viable count (DVC).Homogenates of algae and $1.0 \mathrm{~mL}$ of water from experimental flask and control flask of each set were taken into the eppendorf tubes containing yeast extract $(0.025 \%)$ and nalidixic acid $(0.002 \%)$. The tubes were incubated overnight in a dark place at room temperature. $5 \mu \mathrm{L}$ of sample from each eppendorf tube was placed on PTFE (polytetrafluoroethylene) coated well glass slides and were air dried and flame fixed. Then one drop $(20 \mu \mathrm{L})$ of $1: 10 \mathrm{~V}$. 
cholerae $\mathrm{O} 139$ polyclonal antiserum (made in ICDDR, B) was added to the wells and mixture was incubated at $37^{\circ} \mathrm{C}$ for $30 \mathrm{~min}$ in moist chamber. Slides were rinsed in sterile PBS, gently blotted and air dried. Fluorescein isothionate conjugated (FITC) antimouse Ig G (Sigma) $(20 \mu \mathrm{L})$ diluted in PBS (1: 80 ) was added to the wells and incubated for $30 \mathrm{~min}$ at $37^{\circ} \mathrm{C}$. The slides were then washed and mounted under coverslip with FA mounting oil. Finally the slides were examined under an epifluorescence Microscope (model 2 BH. 2, Olympus), culturable, V.choleraei $\mathrm{O} 139$ was used as a positive control.

\section{RESULTS AND DISCUSSION}

The Fig. 1 showed the survival pattern of $V$. cholerae $\mathrm{O} 139$ with Anabaena sp. in artificial sea water. In control flask water the culturable count increased $1.038 \log _{10} \mathrm{CFU} \mathrm{mL} \mathrm{m}^{-1}$ from $0 \mathrm{~h}-24 \mathrm{~h}$ Then culturable count slightly decreased throughout 2 nd day, 4th day and 6th day reading and reduced to $3.374 \log$ at 9th day. After that no culturable V. cholerae O139 could be detected even after enrichment in APW. Incase of water where Anabaena sp. was floating (supernatant) the culturable count increased $1.113 \mathrm{log}$ from $0-4 \mathrm{~h}$ and then the culturable count of $V$. cholerae O139 decreased to $2.225 \mathrm{log}$ at 6th day. In association with algae the culturable count increased $0.961 \log$ at 4th day of sampling.

In the control flask of distilled water (Fig. 2) the culturable count increased $0.873 \log$ from $0 \mathrm{~h}$ to day 3 . This count slightly decreased an amount of $0.382 \log$ on day 9. In case of water where Anabaena sp. was floating the culturable count decreased an amount of $3.973 \log$ from $0 \mathrm{~h}$ to day 3 . In association with algae the culturable count increased $0.312 \log$ from $0 \mathrm{~h}-4 \mathrm{~h}$. This culturable count deceased an amount of $2.523 \mathrm{log}$ at 3 rd day reading.

In control flask of river water (Fig. 3) the culturable count increased $0.056 \log$ from $0-6 \mathrm{~h}$. Then culturable count gradually decreased $3.398 \log$ at day 4 . In case of water where Anabaena sp. was floating the culturable count gradually decreased $0.306 \log$ from $0 \mathrm{~h}$ to day 2. In association with algae the culturable count gradually increased $0.286 \log$ from $0 \mathrm{~h}$ to day 2 . This culturable count deceased $1.136 \log$ at day 4 .

Figure 4 showed the survival and culturable pattern of $V$. cholerae $\mathrm{O} 139$ with Anabaena sp. in BOD dilution water. In contol flask water, the culturable count increased $0.325 \log$ from $0 \mathrm{~h}$ to day 4 . Incase of control water, $V$. cholerae O139 survived upto 4 days. In case of water where Anabaena sp. was floating the culturable count decreased to $1.19 \log$ from $0 \mathrm{~h}$ of

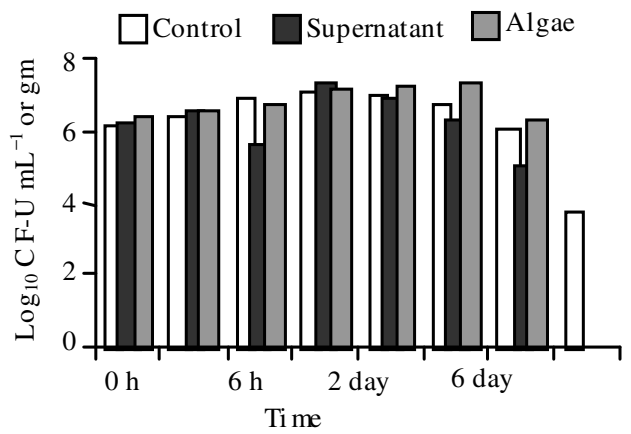

Fig. 1: Culurable count of $V$. cholerae $\mathrm{O} 139$ in artificial sea water microcosm (ph 8.0)

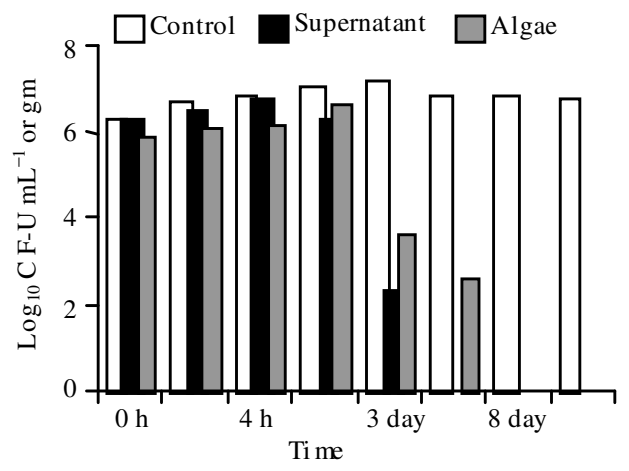

Fig. 2: Culurable count of $V$. cholerae $\mathrm{O} 139$ in distilled water microcosm (ph 8.0)

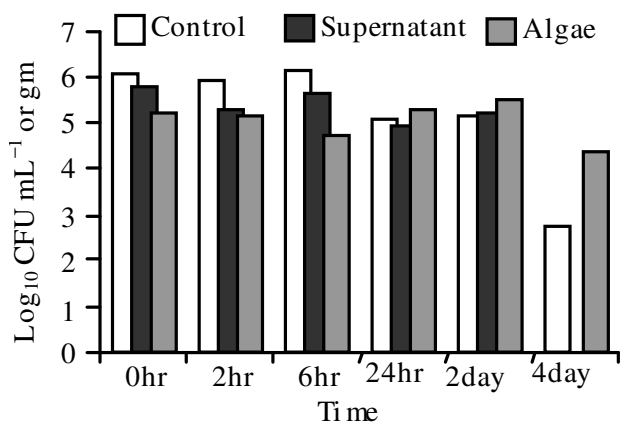

Fig. 3: Culturable count of $V$. cholerae in river water microcosm ( $\mathrm{pH} 7.94)$

sampling to $24 \mathrm{~h}$. In association with algae the culturable count increased $0.488 \mathrm{log}$ from $0-2 \mathrm{~h}$ of sampling but a decrease of $0.322 \mathrm{log}$ was observed at $24 \mathrm{~h}$ reading.

In artificial sea water the multiplication of $V$. cholerae as VBNC state was observed in association with Anabaena sp. (Fig. 5). The initial count of VBNC cell was $6.68 \log 10$ cells/gm which increases to 7.28 
Am. J. Applied Sci., 6 (3): 439-444, 2009

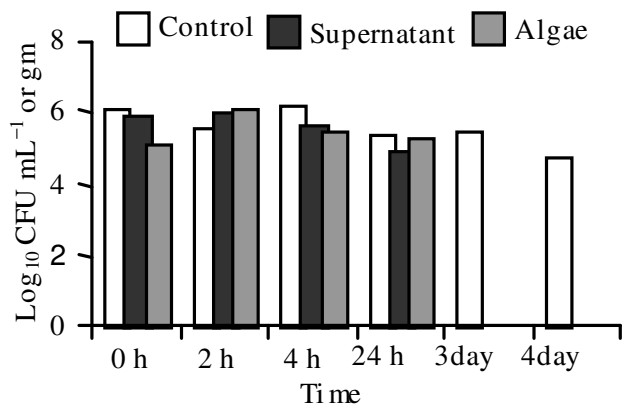

Fig. 4: Culturable count of $V$. cholerae in BOD dilution water $(\mathrm{pH} 7.70)$

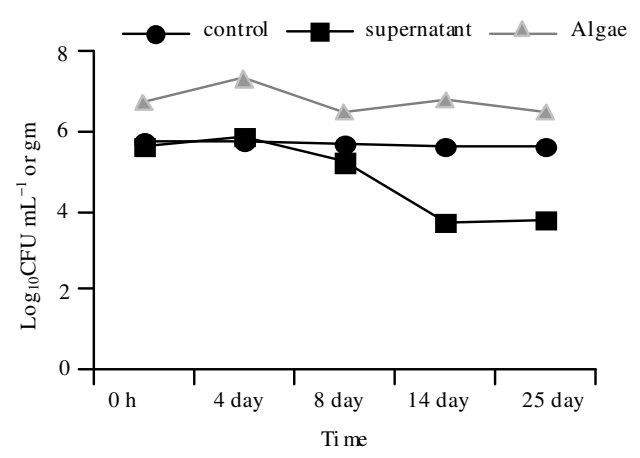

Fig. 5: Flurescent antibody Direct Viable Count (DVC) of $V$. cholerae $\mathrm{O} 139$ in artificial sea water microcosm ( $\mathrm{pH}$ 8.0)

$\log 10$ cells/gm on day 4 and at the end of the experiment, the count was $6.431 \log 10$ cells/gm. The count in algal water at $0 \mathrm{~h}$ was $5.57 \log 10$ cells $/ \mathrm{mL}$, decrease to $3.69 \log 10$ cells $/ \mathrm{mL}$ on days 14 . At 30th day the count was $3.75 \log 10$ cells $/ \mathrm{mL}$. No significant increase or decrease of VBNC count was observed in control water.

In river water the VBNC count of $V$. cholerae in Anabaena sp. was increase to $7.1 \log 10$ cells/gm from the initial $6.11 \log 10$ cells/gm at 8 day while at 14 th day, the count decrease to $4.41 \log 10$ cells $/ \mathrm{mL}$ algal water (Fig. 6). Insignificant changes of VBNC count was found in control water.

In distilled water, the VBNC count of $V$. cholerae either inside or surface of the Anabaena sp. gradually increased at day 8 (from initial $6.15 \log 10$ cells/gm to $8.07 \log 10$ cells/gm) and then gradually decreased to $7.17 \log 10$ cells/gm at day 30 (Fig. 7). In Anabaena water VBNC of V. cholerae maintained a steady state with initial count and the end count $(5.87 \log 10$ cells $/ \mathrm{mL}$ at $0 \mathrm{~h}, 5.44 \log 10$ cells $/ \mathrm{mL}$ at day 30 ). A decrease of $1.01 \log 10$ cells $/ \mathrm{mL}$ was observed in control water from 0 h-day 30 .

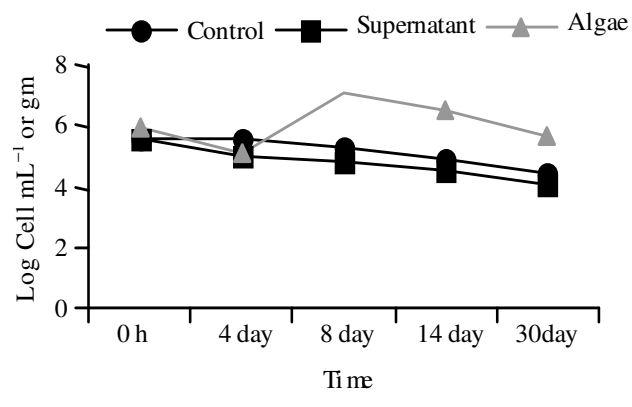

Fig. 6: Flurescent antibody Direct Viable Count (DVC) of $V$. cholerae $\mathrm{O} 139$ in distilled water microcosm ( $\mathrm{pH} 8.0)$

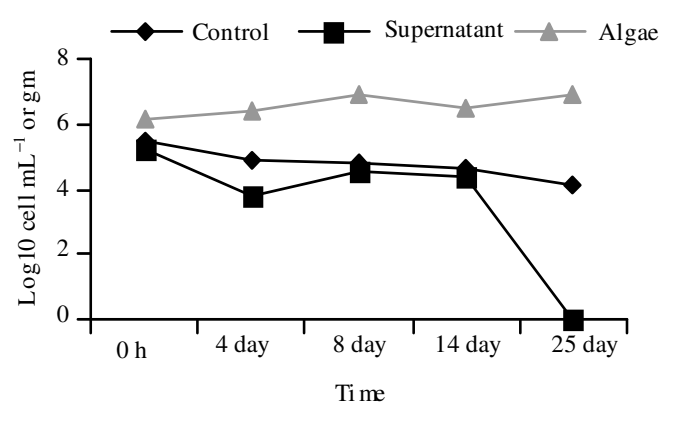

Fig. 7: Flurescent Antibody Direct Viable Count (DVC) of $V$. cholera $\mathrm{O} 139$ in River water microcosm $(\mathrm{pH} 7.94)$

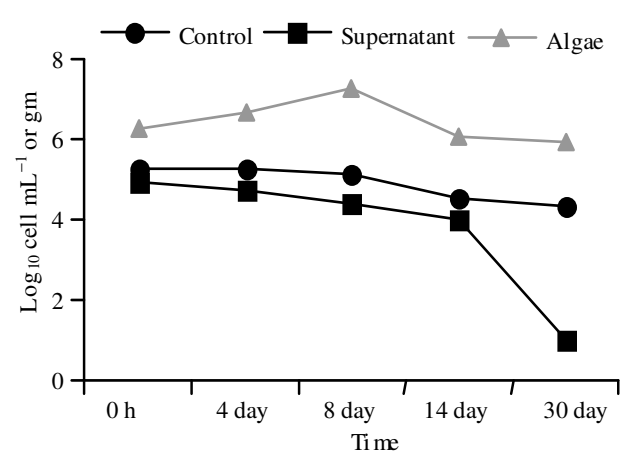

Fig. 8: Flurescent antibody Direct Viable Count (DVC) of $V$. cholerae $\mathrm{O} 139$ in BOD dilution water microcosm ( $\mathrm{pH} 7.70)$

$V$. cholerae $\mathrm{O} 139$ of control water of BOD dilution water, did not show any significant changes in DVC count at $0 \mathrm{~h}$ for DVC was $\log _{10} 5.252$ cells/mL ( Fig. 8). In association with Anabaena sp. the highest count of DVC was found at day $8\left(\log _{10} 7.279\right.$ cells $\left./ \mathrm{mL}\right)$. After day 8 the DVC counts gradually decreased to $\log _{10}$ 5.960 cells $/ \mathrm{mL}$ at day 30 . In case of water where 
Anabaena sp. was floating, DVC did not differ very much from $0 \mathrm{~h}$ to day $8\left(\log _{10} 4.954\right.$ cells $/ \mathrm{mL}, \log _{10}$ 5.176 cells $/ \mathrm{mL}$ respectively). The DVC could be observed at day 14 sample and onwards.

Artificial sea water provided the best environment for the $V$. cholerae $\mathrm{O} 139$ for more attachment with algae in this experiment. On the other hand, BOD dilution water seemed less friendly for the growth of $V$. cholerae $\mathrm{O} 139$. This suggests that water quality has role in the survival of $V$. cholerae in association with Anabaena sp. This finding can be supported by previous studies. Water quality plays important role in bateria-algal association and transmission of cholera ${ }^{[23,24]}$. Here the culturable count in algal water was inversely proportionate to the count of bacteriaalgal association. Higher count found in algal water at initial stage which gradually decreased within 2-4 days. This trend was completely opposite in bateria-algal association. It inferred that V. cholerae $\mathrm{O} 139$ entered into the mucilaginous sheath of algae for shelter and nutrition. This finding is also supported by the study of Schneider and Parker ${ }^{[25]}$ where they found that $V$. cholerae can secrete an enzyme mucinase which degrade the mucin and mucin like substances present in the plant cells, helps to penetrate bacteria into algae. More studies have demonstrated that blue green algae, Anabaena sp. may act as a reservoir of $V$. cholerae $^{[26]}$. Islam $^{[27]}$ also demonstrated that $V$. cholerae $\mathrm{O} 1$ can survive and attach in association with four marine algae longer period than water surrounding marine algae. This also infers that $V$. cholerae can make association with algae. Strain V. cholerae O139 remained in VBNC in blue-green algae in large number than in control water or in algal water. This result is concordance with another study by Munro ${ }^{[28]}$ where they found that in sea water VBNC $V$. cholerae O1 may survive for some times.

In brief this research leads to following findings: Survival rate of the bacteria with the algae depends on the quality of the water, V. cholerae O139 survives long time in control water because of the absence of nutrient intake by algae and interference of other bacteria and $A$. variabilis can act as a reservoir of $V$. cholerae $\mathrm{O} 139$ where they can hide for long time as VBNC form.

\section{REFERENCE}

1. Islam, M.S., M.G. Goldar, M.N.H. Khan, M.R. Islam and R.B. Sack, 2002. Involvement of the hap gene (mucinase) in the survival of Vibrio cholerae $\mathrm{O} 1$ in association with the blue green alga, Anabaena sp. Can. J. Microbiol., 48: 793795. doi: 10.1139/W02-073.
2. World Health Organization.2007.Cholera.Fact sheet no. 107.World Health Organization, Geneva,

Switzerland. $\leq$ http://www.who.int/mediacentre/fa ctsheets/fs107/en/index.html> (Revised Sep. 2007).

3. Glass, R.I., S. Backer, M.I. Huq, B.J. Stoll, M.U. Khan, M.H. Merson, J.V. Lee and R.E. Black, 1982. Endemic cholera in rural Bangladesh, 1966-1980. Am. J. Immunol., 92: 396-401. http://www.ncbi.nlm.nih.gov /pubmed /7148820.

4. Khan, M.U., M. Shahidullah, M.S. Haque and W.U. Ahamed, 1984. Presence of Vibrios in surface water and their relation with cholera in the community. Trop Geogr. Med., 36: 335-340. http://www.ncbi.nlm.nih.gov/pubmed/6335611.

5. Albert, M.J., M. Ansaruzzaman, P.K. Bardhan, A.S.G. Faruque, S.M. Faruque, M.S. Islam, D. Mahalanabis, R.B. Sack, M.A. Salam, M. Siddique, A.K. Yunus and K. Zaman, 1993. Large epidemic of cholera like disease in Bangladesh caused by Vibrio cholerae O139 synonym Bengal. Lancet, 342: 387-390. http://www.ncbi.nlm.nih.gov/pubmed/ 8101899.

6. Islam, M.S., M.K. Hasan, M.A. Miah, M. Yunus, K. Zaman and M.J. Albert, 1994b. Isolation of $V$. cholerae $\mathrm{O} 139$ Bengal from the aquatic environment of Bangladesh: Implication for disease transmission. Applied Environ. Microbiol., 60: 1684-1686. http://www. pubmedcentral.nih.gov/articlerender.fcgi? artid $=2$ 01539.

7. Islam, M.S., M.J. Alam and S.I. Khan, 1995a. Occurrence and distribution of culturable Vibrio cholerae $\mathrm{O} 1$ in aquatic environments of Bangladesh. Int. J. Environ. Stud., 47: 217-223. http://cat.inist.fr/?aModele $=$ afficheN\&cpsidt $=31$ 53708.

8. Blake, P.A., D.T. Allegra and J.D. Snyder, 1980. Cholera a possible endemic focus in the United States. N. Eng. J. Med., 302: 305-309. http://www.ncbi.nlm.nih.gov/pubmed/7350497.

9. Janda, J.M., C. Powers, R.G. Bryant and S.L. Abbott, 1988. Current perspectives on the epidemiology and pathogenesis of clinically significant Vibrio spp. Clin. Microbiol. Rev. 1: 245-267. http://www.ncbi.nlm.nih.gov/pubmed/ 3058295.

10. Lipp, E.K., A. Huq and R.R. Colwell, 2002. Effects of global climate on infectious disease: The cholera model. Clin. Microbiol. Rev., 15: 757-770. doi: 10.1128/CMR.15.4.757-770.2002. 
11. Huq, A., E.B. Small, P.A. West, M.I. Huq, R. Rahman and R.R. Colwell, 1983. Ecological relationship between Vibrio cholerae and planktonic crustacean copepods. Applied Environ. Microbiol. 45: 275-283. http://aem.asm.org/cgi/content/abstract/45/1/275.

12. Islam, M.S., Drasar, B.S. and Bradley, D.J. 1990. Survival of toxigenic Vibrio cholerae $\mathrm{Ol}$ with a common duckweed, Lemna minor, in artificial aquatic ecosystems. Trans. R. Soc. Trop. Med. Hyg. $<$ javascript:AL_get(this, \%20'jour',\%20'Trans\%2 0R\%20Soc\%20Trop\%20Med\%20Hyg.');>84:422 -4. http://www.ncbi.nlm.nih.gov/pubmed 2260179.

13. Islam, M.S., B.S. Drasar and D.J. Bradley, 1990b. Long term persistence of toxigenic Vibrio cholerae $\mathrm{O} 1$ in the mucilaginous sheath of bluegreen algae, Anabaena variabilis. J. Trop. Med. Hyg., 93 : 133-139. http://journals.elsevierhealth.com/periodicals/ym ai/medline/record/MDLN.2109096.

14. Pruzzo, C., R. Tarsi, M.M. Lleò, C. Signoretto, M. Zampini, L. Pane, R.R. Colwell and P. Canepari, 2003. Persistence of adhesive properties in Vibrio cholerae after long-term exposure to sea water. Environ. Microbiol., 5: 850-858. http://www.ncbi.nlm.nih.gov/pubmed/ 14510838.

15. Feachem, R.G., 1981. Environmental aspects of cholera epidemiology: A review of selected topics. Reports of endemic and epidemic situations during 1961-1980. Trop. Dis. Bull. 78: 675-698. http://www.ncbi.nlm.nih.gov/ pubmed/7022972.

16. Islam, M.S., B.S. Drasar and R.B. Sack, 1996b. Ecology of Vibrio cholerae: Role of Aquatic Fauna and Flora. In: Cholera and the Ecology of Vibrio cholerae, Drasar, B.S. and B.D. Forrest, (Eds.). Chapman and Hall, London. http://books.google.com/books?id=NNQtXqqnV SIC\&pg=PA187\&lpg=PA187\&dq=Ecology+of + Vibrio+cholerae+:+role+of+aquatic+fauna+and+ flora.\&source $=$ web\&ots $=$ GkH_aDIabi\&sig $=$ LtY Dngch0Vkj6cCGIXHdYF3utOo\&hl=en\&sa=X\& oi=book_result\&resnum $=1 \&$ ct=result.

17. Tison, D.L., 1999. Vibrio. In Manual of Clinical Microbiology. 7th Edn. Murray, P.R., E.J. Baron, M.A. Pfaller, F.C. Tenover and R.H. Yolken, American Society for Microbiology, Washington, D.C, pp: 497-506. http://www.pnas.org/cgi/content/full/192426499/ DC1/1.
18. Hoben, H.J. and P. Somasegaran, 1982. Comparison of the pour, spread and drop plate method for enumeration of Rhizobium spp. In inoculants made from presterilized peat. Applied Environ. Microbiol., 44: 1246-1247. http://www.ncbi.nlm.nih.gov/pubmed/MC242176.

19. Kester, D.R., I.W. Duedall, D.N. Connors and R.M. Pytkowicz, 1967. Preparation of Sea water. Limnology Oceanography, 12: 176-179. http://aslo.org/lo/toc/vol_12/issue_1/0176.pdf.

20. ASTM Standard Methods for the Examination of Water and Wastewater. 1998. 20th edn, American Public Health Association/American Water Works Association/Water Environment Federation, Washington DC, USA. (MLSS) p. 2-57 (2540 D) and (COD) p. 5-14 (5220 B).

21. Monsur, K.A., 1961. A highly selective gelatintaurocholate tellurite medium for the isolation of Virbrio cholerae. Trans. R. Soc. Trop. Med. Hyg., 55: 440-442. http://www.ncbi. nlm.nih.gov/pubmed/14475439.

22. Islam, M.S., M.K. Hasan, M.A. Miah, F. Quadri, M. Younus, R.B. Sack and M.J. Albert, 1993b. Isolation of $V$. cholerae O139 Bengal from water in Bangladesh. Lancet, 342: 430. http://www.ncbi.nlm.nih.gov/pubmed/8101919.

23. Islam, M.S. and R.B. Sack, 1992. Cholera epidemics in Bangladesh 1985-1991. J. Diarrhoeal. Dis. Res. 10: 79-86. 24. http://www.ncbi.nlm.nih.gov/pubmed/1500643.

24. Islam, M.S., B.S. Drasar and R.B. Sack, 1994a. Probable role of blue green algae in maintaining endimicity and seasonality of cholera in Bangladesh: A hypothesis. J. Diarr. Dis. Res., 12: 245-256. http://www.ncbi.nlm.nih.gov/pubmed/7751564.

25. Schneider, D.R. and C.D. Parker, 1982. Purification and characterization of the mucinase of Vibrio cholerae. J. Infect. Dis., 145: 474-482. http://lib.bioinfo.pl/pmid:7069228.

26. Islam, M.S., B.S. Drasar and R.B. Sack, 1993a. The aquatic environment as reservoir of Vibrio cholerae: A review. J. Diarrhoea. Dis. Res., 11: 197-206. http://www.ncbi.nlm.nih.gov/pubmed/8188990.

27. Islam, M.S., B.S. Drasar and D.J. Bradley, 1989. Attachment of toxigenic Vibrio cholerae $\mathrm{O} 1$ to various fresh water plants and survival with a filamentous green alga Rhizoclonium fontanium. J. Trop. Med. Hyg. 92: $396-401$. http://www.ncbi.nlm.nih.gov/pubmed/2607573.

28. Munro, P.M. and R.R. Cowell, 1996. Fate of Vibrio cholerae $\mathrm{O} 1$ in sea water microcosms. Water. Res., 30: 47- 50. Doi: 10.1016/00431354(95)00137-A. 